\title{
Antjie Krog's Mede-wete/Synapse as a challenge to new ways of comparative reading
}

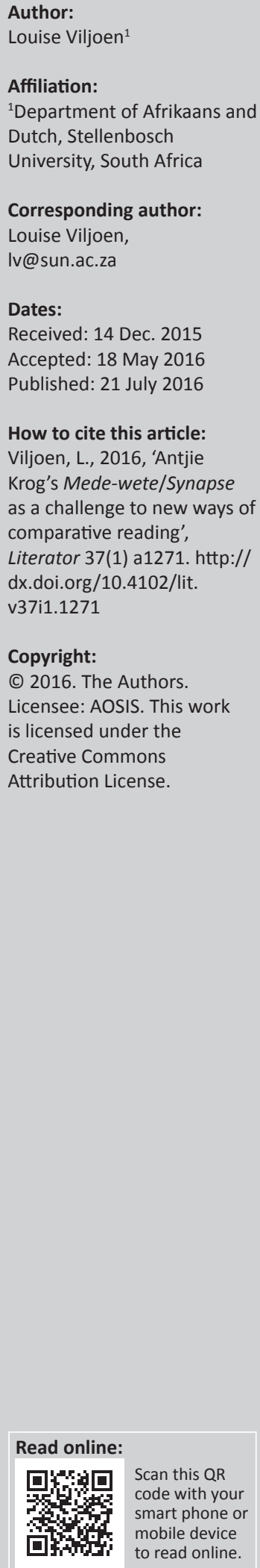

This article reads Antjie Krog's volume of poetry Mede-wete and its English version Synapse (both published in 2014) against the background of Rebecca Walkowitz's proposal that the future of comparative literature will entail what she calls 'foreign reading'. In her contribution to the American Association of Comparative Literature's 2015 report on the state of the discipline of comparative literature (http://stateofthediscipline.acla.org) Walkowitz argues that literary texts increasingly enter the world in different languages and that this requires readings that move away from the idea that literary texts 'belong' to a single language, that explore the diverse ways in which they are read in different languages and that acknowledges that literary texts exist in the space created by a language's relationship to other languages. This article takes Walkowitz's observations as the vantage point for a discussion of the ways in which Krog's volume (1) foreignises the Afrikaans language in order to become part of an interconnected whole; (2) urges readers, critics and literary practitioners to move beyond the confines of language-based literary systems; and (3) forces them to engage in a variety of different readings, including partial readings and collaborative readings, in order to become embedded in a larger community.

Antjie Krog se bundel Mede-wete/Synapse as 'n uitdaging tot nuwe vorme van vergelykende lees. Hierdie artikel lees Antjie Krog se bundel Mede-wete en die Engelse weergawe daarvan Synapse (beide gepubliseer in 2014) teen die agtergrond van Rebecca Walkowitz se voorstel dat die toekoms van die vergelykende literatuurstudie die konsep van uitheemse lesing (foreign reading) sal insluit. In haar bydrae tot die American Association of Comparative Literature se verslag oor die stand van die dissipline van vergelykende literatuurstudie in 2015 (http:// stateofthediscipline.acla.org) argumenteer Walkowitz dat literêre tekste toenemend die wêreld binnekom in verskillende tale en dat dit lesings vereis wat wegbeweeg van die idee dat literêre tekste aan 'n bepaalde taal 'behoort', wat ondersoek sal instel na die verskillende maniere waarop hulle gelees word in verskillende tale en wat erken dat literêre tekste bestaan in die ruimte geskep deur ' $n$ taal se verhouding met ander tale. Die artikel neem Walkowitz se observasies as die uitgangspunt vir 'n bespreking van die wyse waarop Krog se bundel (1) die taal Afrikaans vreemd maak sodat dit deel kan word van 'n intergekonnekteerde geheel, (2) daarop aandring dat lesers, kritici en literatore buite die beperkinge van taal-gebaseerde literêre sisteme beweeg, en (3) lesers dwing om verskillende soorte lesings, waaronder gedeeltelike (partial) lesings en deelnemende of samewerkende (collaborative) lesings, te beoefen sodat hulle deel kan word van 'n groter gemeenskap.

\section{Introduction}

The American Association of Comparative Literature's 2015 report on the state of the discipline of comparative literature consists of a variety of contributions from academics who give their views on the most important ideas of the previous decade, influential practices amongst comparatists, the paradigms within which the discipline operates, the facts and figures involved in comparative studies and how the discipline of comparative literature will develop in the future (available on the association's website, see http://stateofthediscipline.acla.org). In her contribution Rebecca Walkowitz (2015) considers the future of reading by asking: 'How will we read literary works in the future? And how does thinking about the future of literary works change the way we read?'

She goes on to argue that literary texts increasingly enter the world in different languages, as is the case when 'original' texts are published simultaneously with their translations into other languages. According to her, this requires what she calls a 'foreign reading'. Such a reading has certain characteristics and requires asking certain questions. It is a kind of reading that is moving away from the idea that literary texts 'belong' to one language because they can now be accessed 
from various points and in a variety of languages. It will also alter our approach to the 'location of texts' because they can now belong to several territories. It will thus have an impact on the way we think about expert readers or specialists who can read the text in the 'original' language or those who have access to the experience(s) described in the texts.

According to Walkowitz (2015), this situation also requires us to think about the ways in which texts function in more than one language, the diverse ways in which they are read in different languages and the manner in which they are used in literary as well as non-literary cultures. This approach will enable us to consider how texts 'enter, alter, mix, and depart languages' (Walkowitz 2015), reminding us of the fact that languages exist in relation to other languages and that literary texts are produced within the tensions that form part of those relations. This kind of reading will pay attention to those elements in a literary text 'that operate across languages as well as elements that do not move languages easily: typography as well as idiom, plot as well as pun'. Such a 'foreign reading' does not lead to the neutralising of a language's history, but rather to an acknowledgement of its specificities - Walkowitz (2015) argues that engaging with a work's history enables us to 'acknowledge its possible future in other languages, other media and also works'. Because there is nothing neutral about the history of languages, she writes, we should understand languages 'mechanically rather than sentimentally', that is with an eye for the mechanics of the way in which they function rather than from the perspective of a sentimental or emotional attachment.

Reading Walkowitz's vision of the future of comparative literary studies and her account of foreign reading, I was struck by the fact that the work of the South African writer Antjie Krog anticipates exactly this kind of reading, in fact requires such a reading. I am thinking specifically of Krog's most recent publication, the volume of poetry published in Afrikaans as Mede-wete, simultaneously with its English translation Synapse in November 2014. The Dutch translation, Medeweten, followed in January 2015 in an edition that gives both the Afrikaans original and the Dutch translation in a bilingual layout. A few of the poems in Mede-wete were also included in a selection of Krog's poems translated into German and published as Körper, Beraubt in 2014. In this case some poems were translated from Afrikaans and others from English, with the German version of the poem published next to its counterpart in either Afrikaans or English.

My article focuses on Krog's Mede-wete/Synapse because it challenges us to reconsider the ways in which we read and to revise the manner in which we conduct (comparative) literary studies, not only in Afrikaans but also in the other South African languages. As such, Krog's text manages to foreground several of the issues that Walkowitz mentions in her vision of the future of comparative literature. I focus my attention on only a few of the many facets of this rich and complex volume in order to understand some of the ways in which Krog's text challenges the reader to a foreign reading: the foreignising of language in the cycle 'Four aspects of linguistic synapse tracing', the call for Afrikaans readers and critics to engage with the larger world in the poem 'ESSAY ABSTRACTS: re Synapse' and the attempt to imagine the other in the cycle 'servants talk'.

\section{Close reading, distant reading, foreign reading: Considering the titles Mede-wete and Synapse}

The term 'foreign reading', as described by Walkowitz (2015), resonates with two other terms often used in debates on the methods used in studies of comparative literature and world literature, namely 'close reading' and 'distant reading'. Close reading is often seen as the provenance of specialists who have an intimate knowledge of national literatures, whereas distant reading is associated with the sphere of comparative literature and world literature, as Moretti (2000) argued.

Although comparative literature developed by setting itself off against the practice of focusing exclusively on a national language and its literary tradition, Haun Saussy (2006:9-11) writes that comparative literature nevertheless has 'a close dependency on the very national-languageand-literature disciplines that [it] was created to overcome'. Moretti (2000) proposed the value of distant reading as opposed to close reading within the context of comparative literature and world literature. He argued that close reading depends on a very small canon and invests an inordinate amount of analytical time in the reading of individual texts because of the belief that very few texts really matter; he referred to it as 'a theological exercise', especially prominent in national literary studies in which the texts forming the canon are treated with the utmost reverence. ${ }^{1}$ In the face of this he proposed a distant reading, which 'allows you to focus on units that are much smaller or much larger than the text: devices, themes, tropes - or genres and systems' in an attempt to grasp 'the system in its entirety' (Moretti 2000:57). Moretti used the metaphor of the tree, which presupposes the branching off from unity into diversity and is based on geographical discontinuity, ${ }^{2}$ to describe the work of the specialists of national literature. The metaphor of the wave, on the other hand, was applied to the field of world literature because it depicts a movement that overcomes barriers and thrives on geographical continuity, thus making it possible to describe systems and movements that sweep over the linguistic and geographical barriers posed by national literatures. Moretti (2000:66-68) concluded that distant readings provide the better viewpoint on literature and that the study of world literature should be 'a permanent intellectual challenge to national literatures'.

1.In her essay "Close reading and the global university - notes on localism', Rey Chow (2015) writes the following about close reading: 'In ethnographic terms, what is (2015) writes the following about close reading: In ethnographic terms, what is sometimes invoked in derogation as textualism in this con a practice of localism, wher that can speak for itself while such speech and take note'.

2.'Trees need geographical discontinuity (in order to branch off from each other languages must first be separated in space, just like species)' (Moretti 2000:67) 
The idea of foreign reading that Walkowitz (2015) proposes also questions the notion of close reading, when it is interpreted in Moretti's sense as the arena of those who possess specialist knowledge of a language, literary tradition, literary system or particular experience. The concept of foreign reading, as described by Walkowitz, disrupts several of the notions that the specialists of national literatures hold dear. It questions the idea that texts belong to one language and that they are thus the property of one linguistic or national group. It alters the approach to the location of texts because they are now understood as belonging to several places or territories, thus dislodging the idea that there are 'native readers' who will be better able to access or understand the text than others. This view has certain implications for existing reading practices. It implies that one should reconsider one's own location as reader of a text to realise that it will have many lives in different languages and places. In the face of this realisation it might be appropriate to question one's privilege as a native speaker of the language the text was first written in as well as one's authority as a literary practitioner in a specific literary system. Approaching literary texts from this vantage point would constitute a challenge to South African literary studies that still operate in separate language-based departments and rarely speak to one another across this specialist divide. ${ }^{3}$ A foreign reading does not imply that one disowns the histories, specificities and relationships of the language in which a text was written, but rather that one will resist one's sentimental attachment to a specific language, Walkowitz (2015) notes.

It is my argument that the intellectual project underlying Krog's volume Mede-wete/Synapse challenges the reader to a foreign reading. In many ways the volume is an expression of the urgent need ${ }^{4}$ to become interconnected, not only with others in the larger South African community but also with the planet in all its many facets and the larger universe of which it forms part. In an interview with Manuela Kalsky, Krog contrasts the Western philosophical tradition that prioritises the individual with an African tradition that values communality and sees the individual as fully rooted in plurality, interwovenness and interconnectedness (Kalsky $\&$ Krog 2014). ${ }^{5}$ She expresses the desire to think of the self as divided into many (totaal verdeeld in talle), refusing at all times to fall back into the dichotomy of self and other - to coin a phrase: the self is many others; the self is a we.

Displacing oneself from one's mother tongue to the medium of a second language (in this case from reading Krog's volume of poetry in the original Afrikaans to reading the English translation) might be one way for an Afrikaans reader to respond to Krog's challenge to address the failure of the creative and critical imagination to become interconnected and embedded in a larger literary community. Another is to

3.See the heated debates around the topic of South African literary historiography (especially Michael Chapman's Southern African literatures), as well as the way in (especially Michae Chaph literature in the introduction to The Cambridge history of South African literature.

4.Ze ademen urgentie' [They breathe urgency], writes the Dutch reviewer Joop Leibbrand (2015) of the poems in the volume.

5.See Van Niekerk (2015) for a discussion of this issue in Krog's transformation trilogy, Country of my skull, A change of tongue and Begging to be black. 'foreignise' one's reading as a specialist in order to consider the trajectories of the text in different languages and cultures and to consider the way in which this text takes cognisance of its existence within the tension between languages - in short to displace oneself from one's privilege as a native speaker or reader.

The movement from the Afrikaans volume's title Mede-wete to that of the English volume Synapse demonstrates the different lives or meanings the text can assume in different languages. The Afrikaans word mede-wete literally means something that you know with another; it thus refers to a knowledge shared with others, with the added dimension of complicity when it refers to something that happens with one's knowledge and consent. The first section of the volume is titled 'die werf' [the yard]. The mottos introducing this section highlight the fact that the Dutch origins of the Afrikaans word werf implies the act of fencing in and constructing an enclosure $\left(9^{6}\right)$. It is thus to be expected that the volume focuses, amongst others, on the histories, categories, laws and conventions through which some people are included and others excluded from a specific space, something that might lead to mutual ignorance and resentment (as evidenced by the history of South Africa). Read against this background, the Afrikaans title Mede-wete might also imply the desire to know of others and to know with others, those others that find themselves outside the confines of your own yard.

The Chambers 21st Century Dictionary defines the word chosen as title for the English version of the volume, Synapse, ${ }^{7}$ as follows: 'a region where one neuron communicates with the next, consisting of a minute gap across which nerve impulses are transmitted by means of a chemical substance known as a neurotransmitter [19c: from Greek synapsis contact or junction $]^{\prime} .{ }^{8}$ Whereas the Afrikaans title emphasises the togetherness of knowing and also includes the idea of responsibility inherent in the concept of complicity, the English title implies that a 'gap' has to be bridged in order to communicate, as in the case of neurons. The idea of the 'gap' is taken up later in the volume in a reference to Spivak's $A$ Moral Dilemma, in which the latter refers to the fact that our inability to reach 'the quite-other' is the 'founding gap in all act or talk, most especially in acts or talk that we understand to be closest to the ethical - the historical and the political' (60). Going back to its etymological roots, Visagie (2015:226) reads the word synapse as a reference to 'conjunction', to the act of joining together or connecting with. He points out that the 'synapsing of the self' or connecting with others in Medewete/Synapse is realised in the depiction of relationships with loved ones, the attempt to overcome cultural difference and the desire to achieve union with the non-human, nature and the universe in a realisation of shared materiality.

6.Page numbers without reference to author or date refer to the following text: Krog, Antjie, 2014b, Synapse, Human \& Rousseau, Cape Town.

7.Van Niekerk (2014) points out that the volume's English title, Synapse, might have originated in Krog's conversations with the Australian philosopher Paul Patton, recorded in her nonfictional text Begging to be black. See Krog 2009a:95.

8.See the Chambers 21st Century Dictionary definition of the word 'synapse', viewed 05 April 2-15, from http://ez.sun.ac.za/login?url=http://search.credoreference. com/content/entry/chambdict/synapse/0 
Although Walkowitz speaks from the perspective of the dominant language English and wants to find a way out of thinking monolingually (as is also evident from her essay 'Close reading in an age of global writing' [Walkowitz 2013] with its references to 'non-translation studies' and 'untranslationist' works), her ideas can serve as a timely reminder for South African literary practitioners to move beyond their comfort zones to question their own presuppositions and engage with material beyond their own fields of expertise. Read in combination with Krog's exhortation to bridge or supplement the gap between an individualised self and a pluralised community, it may also hold a lesson for South African writers, critics and translators.

\section{Renewing the self through renewing language: 'Four efforts in syllabic synapse tracing'}

In her poetic attempt at transforming the individualised self into a plural and multiple other, Krog is by her own admission guided and inspired by the German poet Paul Celan. During the time she spent at the Wissenschaftskolleg in Berlin from 2007 to 2008, one of the other fellows, Michael Fried, invited her to join him for private tuition on the work of Celan, during which they were asked to translate Celan's poetry, 'syllable by syllable'. In an interview with Louis Esterhuizen, Krog relates how her own use of Afrikaans was changed during the process of translation, how she literally had to exercise speech muscles and tendons that had become calcified and recalcitrant. ${ }^{9}$ She describes Celan's techniques of breaking down German through the use of neologisms and morphological deviations, citing Shira Wolosky (1999), who wrote: '[Celan's] work never resides fully or comfortably in any native tongue' (Esterhuizen \& Krog 2014). It is by means of reading and translating Celan that Krog felt she could radically change her own use of Afrikaans: 'Op hierdie manier kon ek langsamerhand my estetiek (diep geleë in Afrikaans) laat sny deur 'n etiek in hoe Afrikaans teenoor die ander sou klink' [In this way I could gradually make my aesthetic sense, deeply rooted in Afrikaans, cut though an ethics of how Afrikaans would sound to the other] (Esterhuizen \& Krog 2014). Elsewhere she articulates her feelings about the compromised status of Afrikaans as follows: 'To remain inside Afrikaans poetry became only possible through transformations brought about by intersecting aesthetics (my deep love and embeddedness in Afrikaans poetry) with ethics ${ }^{10}$ (my understanding of what went wrong

9. Krog describes it as follows in the interview (Esterhuizen \& Krog 2014): "Ek het dit dus eers in Afrikaans gesê en dan stuk-stuk in Engels en na'n ruk begin agterkom hoe anders my Afrikaans begin klink. Asof gimnastiek gedoen word om verharde, verkalkte of selfs nie-bestaande spiere en senings te strek deur middel van ' $h$ diepgekwelde poëtiese taal wat begin vorm aanneem op my tong." II first said it in Afrikaans and then piece by piece in English and after a while I realised how different my Afrikaans began to sound. As if gymnastic exercises were being done to stretch hardened, calcified or even non-existing muscles and tendons by means of a deeply poetic language that began to take form on my tongue.]

10.Krog does not explain or unpack her own use of the word 'ethics'. The reade gathers that she uses it in the general sense of 'moral principles that govern a person's behaviour or the conducting of an activity' (see The Oxford Dictionary of English definition of the word 'ethics', viewed 4 April 2015, from http://www. oxforddictionaries.com/definition/english/ethics). This is a topic for further oxforddictionaries.com/definition/english/ethics). among Afrikaners and how a world from within Afrikaans towards others could be)' (quoted by Press 2014:119).

Included in the list of sources that Krog acknowledges in Mede-wete/Synapse is Amir Eshel's essay Paul Celan's Other: History, Poetics and Ethics (Eshel 2004), which gives important clues about the way in which Celan's view of poetry might have influenced Krog's attempt to change her conception of the individual self into a plural 'we' by means of a change in language. Eshel (2004:57-58) cites the famously ambiguous statement ${ }^{11}$ from Celan's 'Meridian speech' on the acceptance of the Büchner Prize in 1960:

The poem intends another, needs this other, needs one across from it. It goes towards it, bespeaks it. [Es sucht es auf, es spricht sich ihm $z u$.] For the poem heading toward the other, everything and everyone is a figure of this other.

This view of the poem as reaching towards an 'other' (however ambiguous it may be in Celan's formulation, as Eshel 2004:58 points out) clearly coincides with Krog's project of rethinking the notion of self within the framework of African philosophy (she is mindful enough to include the name of the Ghanaian philosopher, Kwame Gyekye, who challenges the view that this idea is based in African philosophy, in one of the poems in Synapse, 112). Eshel mentions several distinctive traits of Celan's poetry that the reader assumes might have inspired or resonated with Krog as a student of Celan's work, both with regard to his ideas about poetry in general and his poetic technique. Eshel's description of Celan's view of poetry 'as a form of dialogue, encounter, and provocation that avoids the reduction of the other to a single realm of signification and that thus constantly points toward a non-utopian, yet decisively ethical horizon' (Eshel 2004:59) and 'the linguistic realm that sets itself free from the restriction of hegemonic, communicative discourse' (Eshel 2004:68) clearly found fertile ground in Krog's attempts to define herself poetically. Eshel's description of Celan's 'poetic disruption of the lexically 'correct' in a specific manner that Celan calls 'Jewification' [verjuden]' (Eshel 2004:67) and of his view that poetry often appears as 'unintelligibility, lack of ordinary syntax, and common semantics' because it is 'the radical other to discursive language' (Eshel 2004:68) also seem to have impacted Krog's poetic practice in Mede-wete and Synapse.

If one wants to draw a further comparison between Celan and Krog (even though she herself avoids doing this), one has to point out that Celan writes from the position of someone who was persecuted by the speakers of his own mother tongue, German, and tried to rehabilitate German because of that; Krog writes from the position of someone who was part of an Afrikaans-speaking group that oppressed others and for that reason feels that she has to rehabilitate Afrikaans in such a way that it can approach those that were oppressed by her people. ${ }^{12}$ Krog states: 'The question I address in this volume

11.Van Vuuren (2014) was the first to refer to Celan's Meridian speech with regards to Krog's volume in her review essay, appearing shortly after the publication of the volume. My reading is indebted to her insights.

12.See also Van Vuuren (2014) on the significant differences between the positions of Celan and Krog. 
is: "How does one write in a language with an unjust past?"' (Van Wyk 2014). Writing poetry that attempts to change that language by breaking it up in the same way that Celan did with German seems to be one way of doing that.

The manifestation of these poetic practices can be found at many points in Synapse and needs a more thorough investigation than this article can offer. The most obvious examples are the cycle of poems 'to become you' (46-51, Afrikaans title om te ver-jy $y^{13}$ ) and the cycle of poems that concludes the volume, 'Four efforts in linguistic synapse tracing' (107-117). In the 'Translator's note' to the volume Synapse, Krog's translator Karen Press writes that the aim with the translation was 'to keep as close to the Afrikaans texts as possible, and to carry over into English the spirit, if not always the letter, of the "breaking open" of familiar languages that is at the core of many of the poems in Medewete' (Press 2014:119). To illustrate what is meant by the 'breaking open' of language, Press (2014:119) also quotes an unpublished essay by Krog in which she writes about her experience of translating Celan's poetry:

Translating these neologisms [...] it was also soon apparent how they brought a kind of strangulation into the poem, a kind of wordknot. This intensified one's attention so that one could not flow further with the poetic line. You had to stop, to think of the two separate concepts, then how they influenced one another. Rhythmically the neologisms also held you back until an opening of understanding allowed the poem's breath to flow further. As a kind of forcefeeding of meaning into a line the neologisms were very powerful.

This quotation shows that the 'organised violence performed on ordinary speech' (to quote Roman Jakobson ${ }^{14}$ ) in this volume by breaking up words is aimed at making the poem, and eventually also the Afrikaans language, breathe anew. This desire also formed part of the title metaphor and content of Krog's text A Change of Tongue (2003) and its Afrikaans version 'n Ander tongval (2005). The aim in Mede-wete is to break open Afrikaans through a variety of linguistic and poetic mechanisms (un-Afrikaans words, ellipsis, aberrant syntax, neologisms, strange arrangements of type on the page, etc. ${ }^{15}$ ) to enable it to carry a new awareness that will enable its speakers to live an un-apart life amongst and connected with others, so that a new 'world from within Afrikaans [can be presented] towards others'. Through the

13.Poetry International annually celebrates Gedichtendag [Poetry Day], for which a prominent Dutch or Flemish poet is asked to write 10 poems. The cycle 'om te verjy' was written for Gedichtendag 2009 and first published in Dutch as Waar ik jou word by Uitgeverij Podium (Krog 2009b). It cites the influences of Celan and word by Uitgeverij Podium (Krog 2009b). It cites the influences
science writer Govert Schilling and his text Evolving Cosmos (2003).

14.See Erlich (1980:219)

15.The Dutch reviewer Gerard Bes (2015) gave a thoughtful summary of the volume's style: 'Over de stijl heeft se geen veilige controle willen uitoefenen, te merken aan de elliptische invallen en beelden, haperende formuleringen, nieuwgevormde woorden, het nagenoeg ontbreken van leestekens en de grilligheid waarmee teksten op die bladspiegel staan. Daaraan is het zoekende af te lezen dat de lezer dwingt méé te zoeken en nergens in het voorbijgaan overheen te lezen. De bundel maakt een indruk van ruwheid die de doorleefde complexiteit van het bestaan van maakt een indruk van ruwheid die de doorleefde complexiteit van het bestaan van binnenuit gestalte geeft.' 'She did not want to exercise a safe control over the style of the volume, which can be seen in the ellyptical incursions and images, faltering formulations, newly formed words, the almost complete lack of punctuation an the capricious way in which the texts are placed on the type page. In searching th reader can deduce from this that he or she is being forced to search with the poet and can never gloss over anything in passing. The volume gives the impression of roughness that gives shape to a lived complexity from the inside out.] translation of these poems the sentiment is carried over and also made applicable to English as a dominant language.

The title 'Four efforts in linguistic synapse tracing' suggests that the movement between synapses can serve as a metaphor for the movements in language, which in its turn can serve as a metaphor for the movement that will bridge the gap between an individualised self and a plural self-embedded in a larger community. The cycle is preceded by the following two stanzas, of which the first uses the image of a dentist's drill opening up blocked and fossilised pieces of language and the second refers to the image of air rushing through the opening thus made, resulting in a new sound and a new language:

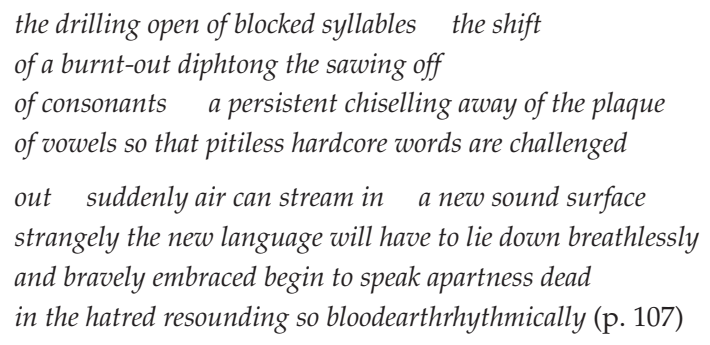

This anticipates the rough treatment that language will be subjected to in the cycle of poems, the brutal handling of language that will be necessary to produce a new sound that will literally be the death of 'apartness'. The awkwardness of the phrase 'to speak apartness dead' in English emphasises the way in which the Afrikaans 'enters and alters' - to use Walkowitz's (2015) words - the English language with the aim of producing a new sound that will perhaps touch a raw nerve.

The extraordinarily complex poems contained in 'Four efforts in linguistic synapse tracing' all attest to the attempt to force language across the gap implied by the synapse metaphor. In the first poem, 'intravenously deficient' (pp. 108-109), the speaker describes her own project. She wanted to:

\author{
[...] purview the truth cleave the shallow \\ grind down the miserly liberate the hopeless lamenters \\ into integration be a stonecutter \\ a priestess of dust \\ a form-eater \\ a regent of \\ earthcrust ardour in \\ universes of benevolence
}

The poet's desire for interconnectedness is such that it becomes a violent attempt at forcing the unwilling to agree to 'integration'. However, the rest of the poem shows her realisation that her ambition to be 'a regent of [...] universes of benevolence' is flawed and shot through with her own 'putrefaction', that she has a 'hybrid morale-weary heart', a 'drooping butcher's arm', an 'ashen jowl' and that she is hanging on to life by one hand. The poem is preceded by a motto from Paul Celan's poem Lyon, Les Archers from which the lines fremdest dich ein, / tiefer are given in the English 
translation by Pierre Joris: 'Instrange yourself / deeper'. ${ }^{16}$ Celan's poem addresses a 'you' that contains many strangers: auch du, mit allem / Eingefremdeten in dir / fremdest dich ein, / tiefer [You too, / with all the instrangedness in you / instrange yourself deeper] (Celan 2005:114). The lines by Celan serve to remind the poet that his or her efforts at becoming other may not be enough - thence the feeling of failure.

The second poem in the cycle goes even further in trying to force language to accommodate the notion of a selfconnected-to-others. The poem is titled 'syllabic synapse in the north / south compass' (110-111) and it seems as if the poet is trying to address a 'you' that encompasses a multitude of others: 'do you hear me / you who are all usandthem'. This 'you' is forced to be one with others by the forcing together of different words in phrases such as 'you who are all usandthem', 'you who are all of usnthem', 'you who are ours'. The 'us' and 'you' are described as 'crueltempered stumps' (wreedmoedige afstompings) living apart from one another. In order to communicate and achieve this unity, a 'signal' has to bridge 'the synaptic cleft'. The movement of language is likened to the movement of nerve impulses across the synapses (as indicated before, the Chambers 21st Century Dictionary defines a synapse as the 'minute gap across which nerve impulses are transmitted'). The poet's plea is:

cruel-tempered stumps: signal through the synaptic cleft all yours ours all earth's-us poor's-us hunger's-us

asone(ach)other wash everyo(ur)ne's feet feed eachother with other's mouths

fullfillments with eachsalvingother

The desperate desire to become a self-embedded in community necessitates a new vocabulary. This explains the brutal forcing together of syllables in foreign-sounding constructions such as 'earth's-us', 'poor's-us', 'hunger's-us', 'asone(ach)other' and 'everyo(ur)ne's'. The same goes for the Afrikaans equivalents of these words: aard'le, arm'le, honger'le' en 'ons'le (Krog 2014a:114-115). In the Afrikaans the forcing together of the two words and their related concepts (e.g. aard-hulle, arm-hulle, honger-hulle, ons-hulle) is emphasised by erasing part of the word hulle[them]. ${ }^{17}$ It is only by exerting this extreme pressure on language that the poet feels 'the toils of apartgated earths [will] float loose'. The pressure to connect and unite is such that it is carried over into the English translation and by implication also into the English language.

The third and fourth poems in the cycle both deviate from conventional poetic form. The third poem presents the reader with nine 'ESSAY ABSTRACTS: re Synapse', each consisting of short sentences, phrases or words, followed by a series of keywords on a variety of topics, mostly concerned with

16.Taylor $(2010: 245)$ refers to another paraphrase by Popov and McHugh of 'fremdet sich ein' as 'with- / drawing into its otherness' in Into the heart of European poetry.

17.This practice of erasing part of a word is anticipated by Krog's exploration of the theme of haplography (the inadvertent omission of a repeated letter or letters in writing) in an earlier volume of poetry Jerusalemgangers [Jerusalem Travellers] (1985). language, poetry and literature. The topic in the fourth and final poem in the cycle, structured like an academic thesis, is again the attempt at 'mutual connection' and 'manyness' in the self, not only with other human beings but with the full range of what the planet and the cosmos holds, as Van Niekerk (2014) pointed out in her review of Mede-wete. The title of this poem gives an indication of the extraordinary lengths the poet will go to force language to breaking point: the poem is titled 'thesis in stacked syllable disturbances on embeddedness' (115-117). 'Syllable disturbances' abound in this poem, often indicated by adding an extra letter or sound, often in parentheses, to an existing word. I cite a few examples, also giving the Afrikaans to demonstrate the challenges that the translators of the Afrikaans had to meet: 'a dreamstar(k) spasm' ( $n$ droomster $(k)$ self), 'true stubbled eternitybo(u)nded' (oneindigheidsverbondte), indigen(e)ous philosophers (inhomse filosowe), 'charmeyeingly' (sjarmantogig), 'wa(i)lls of wounds' (w(a)onde), 'ha(o)ltered ankles' (enkelha(o)ltes), 'thin consequen(t)ce' (dun danheid), 'we are $\mathrm{g}(\mathrm{th})$ rown redeemable' (aflosbaar is ons gewor $(d) p)$, 'the tree / whsspps the blood gri(ou)p' (die boom / whsspp die bloedgreep), 'unfulfi(a)lling' (onvervu(a)lde), 'deknow(ny)ing' (ontkannend). The way in which the English translation interacts with the Afrikaans may be considered as examples of 'retracing' (see Kirsten \& Feinauer 2014). It may even be seen as an example of the way in which the struggle with Afrikaans contaminates and brutalises the English translation in order to suggest that it may also be necessary for a language such as English to rethink its complicity in oppression.

The poem concludes with two stanzas in which the point is made that 'we' (human beings) do not hear the attempts of animals, plants, the planet and the stars to commune or connect with us. This leads to a shrill condemnation of human beings: '(we ought to be exterminated / as sensedeprived hatewithering greedshitting boxes of / willing fuckals)' (p. 117). Again it is clear that it is the attempt at communing with others that drives the attempt to stretch language to its utmost limits. This kind of language taxes readers to the extreme, challenging them to follow the poet into the extreme foreignness of this language, taunting them in order to extend their own limits.

Krog challenges her readers to commit to her project of renewing language in order to become embedded in a larger community. Whether they care to follow her or not does not seem to matter to the poet. What matters is that she pressurises language into a foreign sound and infuses her own use of language (whether it be the Afrikaans of the original or the English of the translation) with an awareness of its compromised history. It is somewhat ironical that poetry driven by the desire for interconnectedness and community alienated several readers by its density and difficulty. Even specialist readers such as reviewers felt alienated by the density and difficulty of these poems. Szczurek (2014) found this cycle of poems 'obfuscated' and ultimately too much trouble to read. Van Vuuren (2014) judged the English versions of certain Afrikaans poems to be less alienating because they contain fewer strange neologisms. Even the 
German commentators, who were very positive about Krog's work on the whole, were not taken with these 'stark verrätselten Gedichten' [highly enigmatic poems] in a discussion of Körper, Beraubt on German radio (Borchardt 2015).

\section{Forsaking the tin shack: 'ESSAY ABSTRACTS: re Synapse'}

As already mentioned, Krog's volume challenges one to question one's privilege as a native reader of the language the text was originally written in, as well as one's supposed authority as a practitioner in a specific literary system. She does so not only by unmaking Afrikaans to such an extent that it forces Afrikaans readers to reconsider their own position in a compromised language, but also by mocking and satirising the Afrikaans literary system, writers, critics and academics alike. One of the abstracts in 'ESSAY ABSTRACTS: re Synapse' paints a derisory picture of Afrikaans literature (p. 113):

ABSTRACT 7: Afrikaans literature tinshacking its way everyone crouched on the ground floor pushing each other for extra legroom now and again someone pulls the tin door open are you people really still here? someone sings yoohotohoo someone moulds another cockroach shroud

Keywords: dwindleplated-gibegluttons thighshifters-in-flinchinglanguage olduntongueings

Afrikaans literature is criticised for being exactly the opposite of what the poet professes to be her desire: to break open and rebuild (the Afrikaans) language in order to find out 'how a world from within Afrikaans towards others can be', to quote Krog's words (Press 2014:119). By using the metaphor of people cowering together in a tin shack, she paints a picture of the Afrikaans literary system as isolated and insular (secluded in a tin shack), living in intellectual poverty ('everyone crouched on the ground floor' of the shack), squabbling amongst themselves ('pushing each other for extra legroom'), disdained by the outside world ('are you people really still here?'), failing to respond to their context in any relevant or meaningful way (e.g., singing 'yoohotohoo' and moulding 'cockroach shrouds'). The keywords provide the final touches to the criticism. The first keyword is 'dwindleplated-gibegluttons', referring to Afrikaans writers and critics as gluttons for making and receiving taunting remarks ('gibes'), but whose influence is dwindling. ${ }^{18}$ The second keyword refers to 'thighshifters-inflinching-language', suggesting a cohort of literary workers who idly cross and uncross their legs in a language that has become nervous and defensive ('flinching'). The final keyword is 'olduntonguings', implying that these writers and critics are old and unable to use their tongues, that they may eventually fall silent in a language that was not able to renew itself. Van Vuuren's inspired reading of the Afrikaans phrase 'oud-ontongend' should be noted at this point. She reads it as a reference to an early Afrikaans poem by D.F. Malherbe that inspires Krog's satire of Afrikaans literature and leads her to point in a new direction and away from the old sayings in the old tongues. Van Vuuren (2014) concludes: 'Die nuwe digter en die nuwe aanslag sal nie puur esteties te werk gaan nie, maar ' $n$ sterk etiese inslag hê, een wat die gewete kwel van sy lesers' [The new poet and the new approach will not work by purely aesthetic means, but have a strong ethical approach, one that will trouble the conscience of its readers].

The virulent criticism of Afrikaans literature expressed in 'ESSAY ABSTRACT: re Synapse' is an attempt to jolt Afrikaans writers and Afrikaans literary critics out of their set ways and into the postures of 'foreign reading' that will require them to forsake the 'tin shack' in which they are cowering. As such, it presents yet another challenge to follow the poet into the realm of a more conscientised form of literary criticism in which the rigid divisions between different language-based literary systems in South Africa will be transcended. It is my feeling that the poet wants to encourage Afrikaans literary practitioners to engage in transnational movements of the kind that Lionnet and Shih (2005:5-11) describe as 'minor transnationalism'. According to Lionnet and Shih the logic of globalisation is at the same time centripetal and centrifugal: it takes the form of a universal centre or norm that spreads over the world and then pulls in other cultures to be tested against that norm. However they prefer to define transnationalism in such a way that it refers to a space of participation and exchange, not always beholden to large metropolitan centres. Krog seems to urge Afrikaans literary practitioners to break out of their isolation to engage with the other literary systems in South Africa (as she herself did by translating some of the best-known poems in South Africa's indigenous languages into Afrikaans in Met woorde soos met kerse - see Krog 2002). It appears as if it is not only important for her to revitalise the Afrikaans language, but also the Afrikaans literary system, of which she forms part. The fact that only five of the ten essay abstracts were included in the Dutch translation of the volume and that this particular essay abstract was one of those left out indicates that this message was specifically directed at Afrikaans readers. The fact that it was included in the English translation of the volume suggests that it was also directed at other South African readers to shock them out of their language-based silos to become part of an interconnected literary community.

\section{Imagining otherness: 'Servants talk'}

In her explanation of what a 'foreign reading' entails, Walkowitz (2015) argues that such a reading will remind us that 'languages exist in relation to other languages and that works of literature are produced within that relation'. Both the form and content of the cycle of poems 'servants talk' (60-74) demonstrate that the poems in this volume were created within the tension fields and power relations between languages such as Afrikaans, English and isiXhosa in South Africa.

The cycle is preceded by a motto taken from Gayatri Spivak's A moral dilemma referred to earlier: 'Radical alterity - the wholly other - must be thought through imagining. To be 
born human is to be born angled towards another and others. To account for this, the human being presupposes the quiteother. This is the bottom line of being human as being-in-theethical relation. By definition we cannot - no self can - reach the quite-other ... This is the founding gap in all act or talk, most especially in acts or talk that we understand to be closest to the ethical - the historical and the political. We must somehow attempt to supplement the gap.' This motto speaks directly to Krog's project of integrating the self with others and working towards what she sees as an 'ethical' awareness when using language - she writes that her 'kneading of the language assists one to ethically infuse a vocabulary in which the terrible has happened' and that remaining inside Afrikaans poetry was only possible by 'intersecting aesthetics [...] with ethics' (quoted by Press 2014).

As in the case of other poems in this volume, the cycle 'servants talk' undoes conventional poetic form by structuring the type page into three different sections ${ }^{19}$ in two languages. The top section on each page depicts two white employers (they seem to be a couple) in conversation with each other about their servant Victoria. Their conversation is reported in direct discourse in Afrikaans in Mede-wete (translated into English in Synapse) and arranged in lines of verse. The middle section of the page shows the servant talking to a variety of family members and friends; her discourse is given in isiXhosa and also arranged into lines of verse. The bottom section gives a prose translation of the servant's discourse into the language of the employers: either Afrikaans in Medewete or English in Synapse, thus bringing about a complicity between Afrikaans and English as the languages of the masters. The poems also perturb the reader with questions about the veracity and credibility of the servant's discourse. Was it recorded or invented by the poet? Which part is the original and which the translation: the isiXhosa or the Afrikaans and/or English? Can the translations be trusted? ${ }^{20}$ The fact that the text in isiXhosa had to be translated for Afrikaans- and English-speaking readers is a reminder of Walkowitz's (2015) rejoinder that we need 'to find strategies of unforgetting' the histories and debts of those languages that are in dominant positions. This idea is reinforced by the fact that the hierarchy between these two languages and isiXhosa are much the same as those between employer and servant, even though the histories of Afrikaans and English in South Africa differ considerably. Despite Krog's best efforts at conceiving of the self as rooted in community, the poems in the cycle 'servants talk' demonstrate the difficulty of fully realising such interconnectedness in the face of the material inequalities and the linguistic differences with its accompanying cultural implications. ${ }^{21}$

The pattern described above is broken off at two points in the cycle, the first time by the poem 'the snail as chimera on the sleeping subaltern cheek' (p. 66). The poem gives a

19.Krog cites the example of J.M. Coetzee's Diary of a bad year (Esterhuizen \& Krog 2014).

20.Krog herself says in an interview: 'selfs die vertaling is hoogs twyfelagtig' [even the translation is highly questionable] (Esterhuizen \& Krog 2014).

21.See Taljard's (2014) review of Mede-wete on this point. painstakingly detailed description of a snail moving over the cheek of 'the sleeping subaltern'.22 That the snail is in fact a metaphor for the poetical imagination is confirmed by the lines that emphasise the presence of language: 'her feelers rejoice / hydraulically she pumps language'. The poem charts the course of the snail (the imagination become language) over the subaltern's cheek, using references to the snail to describe the poetic process: feeling, probing, sensing, understanding, absorbing, rejoicing, feeling bliss, dreaming and empathising before 'everything fails and she shrinks back into her white coils'. The poem thus paints a picture of the white poet (employer) who carefully tries to represent the black woman (employee) but eventually fails to do so. Whereas the title of the Afrikaans poem is quite clear about the snail as metaphor for the imagination (die slak as verbeelding op die slapende subaltern se wang), the English title implies ('the snail as chimera on the sleeping subaltern cheek') that it is an 'illusion or fabrication of the mind, [...] an unrealizable dream $^{23}$ to think that the poetical imagination will be able to bridge the gap between employer and servant.

This moment of self-reflection in the midst of 'servants talk' is resumed in the poem that concludes the cycle, 'Victoria and the poet' (74). In the first stanza of this poem, an external observer notes that the 'sleeping subaltern' lifts her head from the stone table on which she rested it in order to sleep, 'rubs her face' and 'disappears into the house with vacuum cleaner and mop'. In the second stanza this observer describes the presence of 'the poet':

distressed the poet stands at the study window he believes in the snail the persistent effort of the snail but actually now he should die from self-loathing impotence and sorrow

Whereas the metaphorical snail (imagination, representation) is described as female and white, the poet pictured in this poem is presented as male and middle-class (he stands at the window of a study). ${ }^{24}$ The conclusion of the external observer at the end of the cycle 'servants talk' is that the poet has utterly failed to imagine and represent the subaltern or - in Spivak's words - to cross the 'founding gap in all act and talk' in any significant way. One can deduce this from the fact that he feels the poet 'should die from self-loathing impotence and sorrow' despite the persistent efforts to imagine and represent others. The motto taken from Drucilla Cornell preceding 'servants talk' provides some consolation: '... the noting of the failure of representation itself becomes a form of listening' (p. 60).

The matter of the failure of the poetic imagination is raised elsewhere in the volume: the cycle 'servants talk' is preceded by the poem 'inventory of my poetic bankruptcy' (p. 59), in which the poet provides an inventory of a series of spaces that she is not able to imagine in any way that is appropriate

22. See Spivak's (whose words are used in the motto of 'servants talk' the word subaltern in an interview with De Kock (1992:45-47).

23.See Merriam Webster's Collegiate Dictionary's definition of the word 'chimera', viewed 05 April 2015, from http://ez.sun.ac.za/login?url=http://search credoreference.com/content/entry/mwcollegiate/chimera/0

24.It is interesting that Krog consciously prevents an autobiographical reading of this cycle of poems by making the poet in 'Victoria and the poet' male. 
or justifiable. It seems inevitable that the poem ends with a cry of despair:

11. spaces how to plunge my imagination into this? I don't know how life in these spaces lives

Krog has been severely criticised for the ways in which she theorises the notion of interconnectedness, especially in Begging to be black (e.g., Smith 2009; Du Preez 2009; Renders 2012; Wessels 2012). The criticism of Begging to be black - a text that Michael Wessels (2012:195) describes as a 'unique blend of affect, philosophical conjecture and generic bricolage' has often centred on the question of genre, with more than one commentator feeling that Krog should have used fiction rather than non-fiction. In the following conversation from Begging to be black, Krog explains why she does not want to use fiction (2008:267-268):

\section{'No, I can't, I don't want to write novels'.}

'Why not? With novels you can explore the inner psyche of characters; you can imagine, for example, being black. So what is it about non-fiction that you don't want to give up?'

'The strangeness. Whatever novelistic elements I may use in my non-fiction work, the strangeness is not invented. The strangeness is real, and the fact that I cannot ever really enter the psyche of somebody else, somebody black. The terror and loneliness of that inability is what I don't want to give up on'.

'But how will you live together in your country (or mine) if you don't begin to imagine one another?'

'I want to suggest that at this stage imagination for me is overrated'.

When Tuitt (2013) analyses Begging to be black against the background of the 'aesthetic turn' in law, especially discussions on constitutional transformation in South Africa, she criticises Krog for renouncing aesthetic form (the novel) in favour of a more totalising discipline. She writes:

Whether the aesthetic can remain minor in the face of the allure of more totalising disciplines and the frames of thought common to them is thus crucial to the transformative potential of the aesthetic [within discussions on the South African constitution] Krog's work ceases to claim any minor, rebel status from the moment of its unthinking choice to eschew the simple form of the novel in favour of some speaking frame through which its author could speak with more influence, more authority, more persuasion - to speak, in other words, in the voice of the law. (Tuitt 2013:83)

Although Wessels (2012:193) discusses Begging to be black from a completely different vantage point (the Khoisan origins of Krog's interconnected world view), he comes to much the same conclusion as Tuitt when he writes: 'It might well be that the genre of fiction is better suited to the radical imagining of new forms of sexuality and cross-cultural relationships than Krog's preferred genre of creative nonfiction'.

One could argue that the return to the genre of poetry in Mede-wete/Synapse provides Krog with a space that is more conducive to the challenge of 'becoming minor' (the
Deleuzian theme that Krog explores in Begging to be black). Mede-wete/Synapse clearly continues the intellectual project of Begging to be black (striving for interconnectedness), but now within the ambit of aesthetics, within the space of poetry, which imposes its own laws and opens up new possibilities. It is possible that poetry provides the kind of space in which the transformation of the self into an interconnected ' $\mathrm{we}^{\text {' can }}$ be attempted with a greater emphasis on the senses, feeling and intuition, with a greater tolerance for radical selfcontradiction and ambiguity, with a greater acceptance of hyperbole and radical extremes, with more possibilities as regards metaphoric nuance and shading, with more patience for the brutalising and breaking up of language to explore different facets of meaning than would be the case in discourses such as philosophy, law and science.

I cite a few examples from Krog's volume to illustrate the extremes that poetry can accommodate: the involvement of the senses and body in exploring otherness in 'the snail as chimera on the sleeping subaltern $\operatorname{cheek}^{\prime}$ (p. 66); the contradictory impulses of yearning for interconnectedness in 'to become you' (pp. 46-51) on the one hand and the loathing of fellow human beings in the poems about a bus ride ('[1st attempt: the bus]', p. 79) and a writers' event ('14. [4th attempt: the writers' event]', pp. 96-97) on the other hand; the extreme hyperbole of a couple's screaming fights after their last child leaves home (p. 100) versus the tenderness of poems about grandchildren (pp. 36, 38-39, 40); experiments with poetic form as in the use of exposition and counterexposition in 'hold your ear to the tear in the skin of my country' (pp. 28-29), essay abstracts and a thesis structure in 'Four efforts in linguistic synapse tracing' (pp. 107-117); the shifts between different languages in 'servants talk' (pp. 60-74) and 'Lament on the death of Mandela' (pp. 103-106); the violence committed on ordinary language in 'Four efforts in linguistic synapse tracing' (pp. 107-117); the exploitation of metaphoric language in expressions such as 'quivering dewlap of my alphabet' used to describe the ageing mother (p. 102) and 'shaking dark dahlia-filled four-roomed fist' to describe the heart (p. 109) - the list goes on.

In a discussion about 'creative non-fiction' with Duncan Brown, Krog admitted that she instinctively trusts poetry to help her articulate that which is almost impossible to capture in ordinary language: '[...] as a poet I instinctively tend to trust the capacity of language to capture the in-capture-able at the very moment it stretches into the poetic', she states (Brown \& Krog 2011:58). A more extensive reading of this volume will have to be undertaken to ascertain whether poetry does indeed provide a more appropriate and effective space for responding to the difficult questions this volume poses.

\section{Conclusion}

In the above I have tried to demonstrate that Krog's volume Mede-wete and its English translation Synapse anticipate a foreign reading of the kind that Walkowitz (2015) describes. I have focused on three aspects of Krog's volume in order to 
make my point: her project of renewing the individualised self and changing it into a plural, a multiple other through renewing her mother tongue, Afrikaans, in the cycle 'Four efforts in linguistic synapse tracing'; her admonition to Afrikaans readers and critics to open themselves to outside influences in the poem 'ESSAY ABSTRACTS: re Synapse'; and her attempt to poetically imagine otherness in the cycle of poems 'servants talk'.

In the first case Krog's breaking open of Afrikaans through the use of neologisms and morphological deviations is an acknowledgement of the language's compromised history and an attempt to renew the language so that she can become part of an interconnected whole. The 'foreignising' of the Afrikaans language into a radically new sound induces the Afrikaans-speaking reader into a foreign reading, forcing $\mathrm{him} /$ her to acknowledge that there is no privileged, native or natural position from which to read a text, as Walkowitz (2015) writes: 'Future reading is foreign reading because it implies something about the people who encounter texts: they are not a predictable group, and they are not contained by one territory or ethnos. Future reading also implies something about the nature of the reader's encounter: it is not unique; and it can't be understood as "native" or "natural"'. Thus the Afrikaans-speaking reader of Krog's text is forced to acknowledge the fact that he or she has no privileged position as a reader and no direct access to the experiences related in the text. This coincided with the fact that I foreignised my own reading by commenting on the English version of Krog's text (even though it was informed by my knowledge of Afrikaans). Through the translation and simultaneous publication of Mede-wete and Synapse the insights about the unavailability of a natural or authentic position from which to comment are carried over onto the English version of the Afrikaans text.

The second part of my argument focused on Krog's attempt in the poem 'ESSAY ABSTRACTS: re Synapse' to jolt Afrikaansspeaking readers and critics (and by extension also those who read the text in one of its translated versions) out of the complacency of the ring-fenced readings that one finds in language-based and sometimes isolated literary systems that do not engage with other literary systems on the local and global level. Again this relates to Walkowitz's idea that a foreign reading will be aware of the many lives that a literary text can lead in different languages and different contexts as well as the pathways that it follows in traversing national and other boundaries. This necessitates the evaluation of 'reception at local, regional, and transnational scales' and 'involve[s] analytic strategies that complement reading and that may involve counting; and it will also involve asking how geopolitical histories have shaped what texts mean, where they appear and who can encounter them' (Walkowitz 2015). In this regard Walkowitz's description of foreign reading is partly indebted to Moretti's (2000) idea of a distant reading that will enable one to see larger transnational movements and patterns.
In the third instance the case of the cycle 'servants talk' demonstrates that in some cases readers will only be able to make partial readings. The Afrikaans- or English-speaking reader of Mede-wete and Synapse who does not know isiXhosa will not be able to fully understand the nuances of 'servants talk' (the same applies to the reader who does not know Sotho in the case of the poem 'Lament on the death of Mandela'). Krog's volume thus urges us as readers to move from our sometimes isolated and individualised partial readings towards collaborative readings in which specialists from different fields can assist each other in their understanding of literary works. Krog herself engaged in such a collaborative reading in the publication There was this goat (Krog, Mpolweni \& Ratele 2009) when she joined forces with the linguist Nosisi Mpolweni and the psychologist Kopano Ratele to interpret the seemingly incoherent testimony given by Mrs Konile about the disappearance of her son at the hearings of the Truth and Reconciliation Commission (see Krog 2008:231-235).

The case of Antjie Krog's Mede-wete and its different translations thus provide us with material that not only forces us to exercise our capacity for close reading, but also challenges us to perform foreign, distant, partial and collaborative readings. Krog's impassioned plea for a differently conceived self that moves from an individualised sense of being towards a self-embedded in community is one of the features of her work that challenges readers and literary academics to move beyond the confines of their closely guarded, linguistically ring-fenced close readings into a wider community of readers and readings.

I have used Krog's text because I think it provides, if not an academic programme or a coherent philosophy, then at least the metaphor of mede-wete or the synapse to inspire South African literary academics to move towards collaborative readings, to leave the 'concrete bunkers' (29) or 'tin shacks' (113) of the literary systems they occupy so comfortably and to explore the transnational routes (minor or major) along which one can follow writers or texts, while at same time acknowledging the singularity of the literary artefact in the way that close reading enables one to do.

\section{Acknowledgements Competing interests}

The author declares that she has no financial or personal relationships that may have inappropriately influenced her in writing this article.

\section{References}

Bes, G., 2015, 'Antjie Krog op haar allerbest', viewed 21 March 2015, from http:// www.8weekly.nl/artikel/12189/antjie-krog-vert-robert-van-der-dorsman-janvan-der-haar-en-alfred-schaffer-medeweten-antjie-krog-op-haar-allerbest.html

Attwell, D. \& Attridge, D., 2012, 'Introduction', in D. Atwell, \& D. Attridge, The Cambridge History of South African Literature, Cambridge University Press, $1-13$.

Borchardt, K., 2015, 'Krog, Antjie: Körper, beraubt', Radio SWR2: Burch der Woche 2 February, viewed 4 April, from http://www.swr.de/swr2/literatur/buch-derwoche/antjie-krog-koerper-beraubt/-/id=8316184/did=14982484/nid=8316184/ crazjj/index.html 
Brown, D. \& Krog, A., 2011, 'Creative non-fiction: A conversation', Current Writing 23(1), 57-70.

Celan, P., 2005, Selections, introduced by Pierre Joris (ed.), University of California Press, Berkeley \& Los Angeles.

Chow, R., 2015, 'Close reading and the global university (notes on localism)', in ACLA State of the Discipline Report, viewed 03 March 2015, from http://stateofthediscipline. acla.org/entry/close-reading-and-global-university-notes-localism

De Kock, L., 1992, 'Interview with Gayatri Spivak: New Nation Writers Conference in South Africa', ARIEL Review of International English Literature 23(3), 29-47.

Du Preez, M., 2009, 'Identiteit-selfmoord is beslis nie nodig', Rapport 9 November, p. 29. Erlich, V., 1980, Russian formalism: History - doctrine, Mouton, The Hague.

Eshel, A., 2004, 'Paul Celan's other: History, poetics and ethics', New German Critique $91,57-77$.

Esterhuizen, L. \& Krog, A., 2014, “"Die verweerde liggaam vertaal haar ontologie": Antjie Krog in gesprek met Louis Esterhuizen', Versindaba 30 November, viewed 3 March 2015, from http://versindaba.co.za/2014/11/30/onderhoud-met-antjiekrog/

Kalsky, M. \& Krog, A., 2014, 'Manuela Kalsky in gesprek met Antjie Krog', Vrije Universiteit van Amsterdam 21 January, viewed 03 March 2015, from http://www. nieuwwij.nl/interview/video-manuela-kalsky-gesprek-met-antjie-krog/

Kirsten, E. \& Feinauer, I., 2014, 'Tussen tale:'n stereoskopiese lees van Breyten Breytenbach se oorblyfsel / voice over aan die hand van literêre teorie', LitNet Akademies 11(2), 659-687.

Krog, A., 2002, Met woorde soos met kerse, Kwela Books, Cape Town.

Krog, A., 2008, 'The untranslated self in a translated self', Journal of Analytical Psychology 53, 225-239.

Krog, A., 2009a, Begging to be Black, Random House Struik, Cape Town.

Krog, A., 2009b, Waar ik jou word, Uitgeverij Podium, Rotterdam.

Krog, A., 2014a, Mede-wete, Human \& Rousseau, Cape Town.

Krog, A., 2014b, Synapse, Human \& Rousseau, Cape Town.

Krog, A., Mpolweni, N. \& Ratele, K., 2009, There was this goat. Investigating the truth commission testimony of Notrose Nobomvu Konile, University of Kwazulu-Natal Press, Scottsville.

Leibbrand, J., 2015, 'Goedschikse verkloters', Meander 04 March, viewed 03 April 2015, from http://meandermagazine.net/wp/2015/03/goedschikse-verkloters/

Lionnet, F. \& Shih, S., 2005, Minor transnationalism, Duke University Press, Durham \& London.
Moretti, F., 2000, 'Conjectures on world literature', New Left Review 1, 54-68.

Press, K., 2014, 'Translator's note', in A. Krog (ed.), Synapse, pp. 119-120, Human \& Rousseau, Cape Town.

Renders, L., 2012, 'Op zoek naar Afrika: Over Begging to be Black van Antjie Krog en andere recent verschenen autobiografische teksten', Werkwinkel 7(1), 73-96.

Saussy, H., 2006, 'Exquisite cadavers stitched from fresh nightmares: Of memes, hives and selfish genes', in Saussy, H. (ed.), Comparative literature in an age of globalization, pp. 3-42, Johns Hopkins University Press, Baltimore.

Smith, G., 2009, 'Aching to understand', City Press 29 November, p. 27.

Szczurek, K., 2014, 'Review: Synapse by Antjie Krog', Karina Magdalena Blog 19 December, viewed 03 March 2015, from http://karinamagdalena. com/2014/12/19/review-synapse-by-antjie-krog

Taljard, M., 2014, 'Review: Mede-wete deur Antjie Krog', Versindaba 08 December, viewed 04 April 2015, from http://versindaba.co.za/tag/mede-wete/

Taylor, J., 2010, Into the heart of European poetry, Transaction Publishers, London.

Tuitt, P., 2013, 'Literature, invention and law in South Africa's constitutional transformation', in K. Van Marle \& S. Motha (eds.), Genres of critique. Law, Aesthetics and Liminality, pp. 75-89, Sun Press, Stellenbosch.

Van Niekerk, J., 2014, 'Lewe sonder wete van ander', Rapport 09 December, 13.

Van Niekerk, J., 2015, 'Om te hoort: aspekte van identiteit in Antjie Krog se transformasie-trilogie', Unpublished PhD-thesis, University of Pretoria.

Van Vuuren, H., 2014, 'Resensie-essay: Antjie Krog se Mede-wete', LitNet Akademies 03 December, viewed 3 March 2015, from http://www.litnet.co.za/Article/litnetakademies-resensie-essay-mede-wete-deur-antjie-krog

Van Wyk, B., 2014, “'Mede-wete" the new poetry collection by Prof Antjie Krog', in Scholarship@UWC Highlights 12 November, viewed 04 April 2015, from http:// www.uwc.ac.za/UWCInsight/sholarship@uwc/Pages/Mede-wete-the-newpoetry-collection-by-Prof-Antjie-Krog.aspx\#.VSD4I_mUeSo

Visagie, A., 2015, 'Sinaps-opsporing tussen self en ander in Antjie Krog se Mede-wete (2014)', Tydskrif vir Letterkunde 52(2), 225-234.

Walkowitz, R., 2013, 'Close reading in an age of global writing', Modern Language Quarterly 74(2), 171-195.

Walkowitz, R., 2015, 'Foreign reading', in ACLA State of the Discipline Report, viewed 03 March 2015, from http://stateofthediscipline.acla.org/entry/future-reading

Wessels, M., 2012, 'The Khoisan origins of the interconnected world view in Antjie Krog's Begging to be black', Current Writing 24(2), 186-197.

Wolosky, S., 1999, 'On (mis-)translating Celan', Conditio Judaica 28, 145-154. 